\title{
Sustainability of pastoralists through camel management in hot arid 'Thar desert \\ Champak Bhakat'
}

National Research Centre on Camel, Jorbeer, Bikaner (Rajasthan) 334001

Camel-carts continue to play a crucial role in the Indian farm economy as a cheap mode of transportation of different agricultural commodities. In Thar region the ratio of camel to other herbivore (cattle, buffalo, sheep and goat) was $1: 21.36$. Among the different camel health disorders, parasitic mange case was highest. It was followed by Trypanosomiasis, general fever, respiratory infection, other problems viz. digestive disorders, worm etc. The average annual productivity of commonly grown Thar desert crop were 0.489 tonne/ha for clusterbean (Cyamopsis tetragonoloba) and 0.275 tonne/ha for moth (Vigna aconitifolia). The final return per unit(Rupee)invested was high in clusterbean (Rs 3.36) as compared to moth (Rs 2.29). The average cost of rearing of draft camel was low when compared with cattle and buffalo. The final return per unit (rupee) invested was high in camel (Rs 1.90) when compared with cattle and buffalo (Rs 1.82) in Thar desert. Due to higher production potential, increase narket price and economic advantage clusterbean cultivation for camel farmers is more profitable than moth cultioation, and camel rearing is also profitable when compared with öther livestock rearing in terms of per unit investment.

Key words: Camels, Farm management, Pastoralis, Sustainability

ThE CROP FlELD are low in desertic
land, because of recurrent
drought the farmers of the region rely
heavily on livestock enterprises for
their sustenance.) The camel pasto-
ralists are those populations whose
livelihood is based largely on camel
production. The animal keeping is
their major occupation and at times
diversify into kecping other livestock
mainly sheep, goats and cattle and
involving agricultural operations.
Their vocation is suited to the availa-
ity and exploilation of natural
resources. in the arid and semi-arid
lands, the crop farming is undepen-
dable and least productive. Animal
husbandary under such degraded
lands can be successful only, if the
livestock are basically a stable
protective resource having long-term
viability employment- absorbing

'Scientist and Incharge, Camel Management Unit.

14 capability and income generating capacity. (The livestock should be compatible with crop cultivation instead of competing with it for land

and water resource. Camel rearing enterprise fits well with such requirements. Marketing of camel is an important trade in the Rajasthan

Fig. 1. Camel used in carting operation.

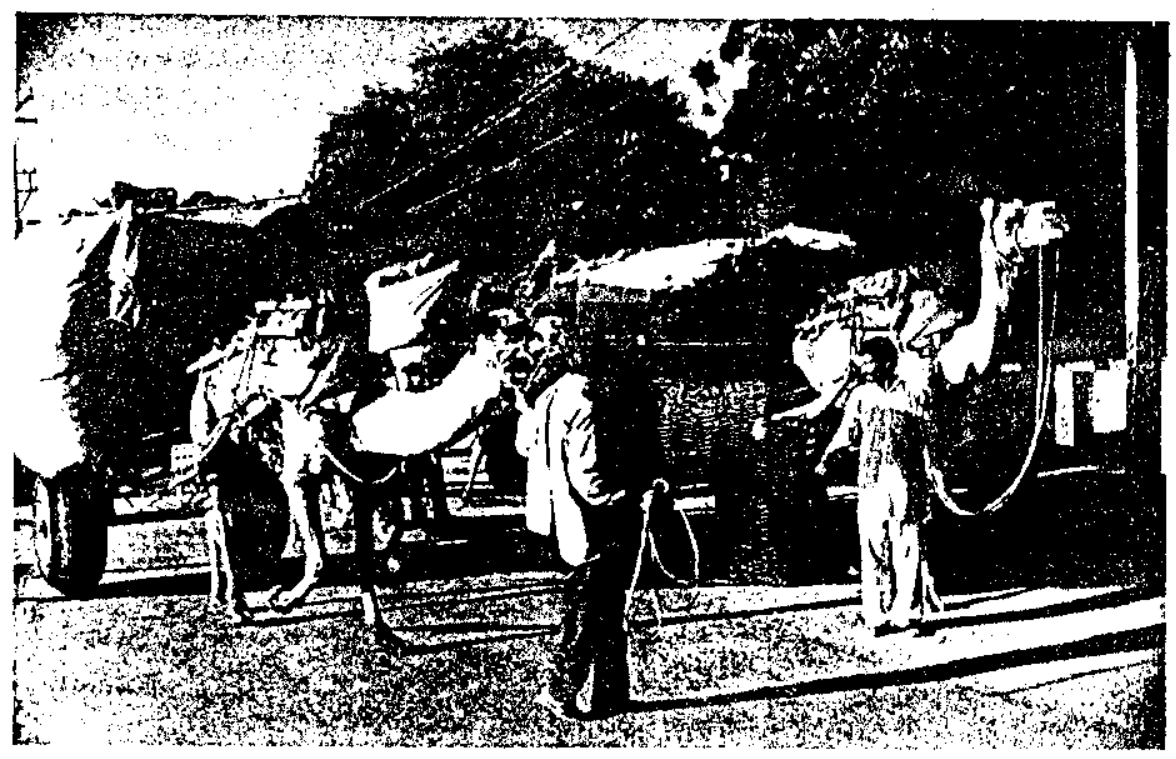

Indian Farming

$$
\begin{gathered}
\text { Vol }-52, N o-11 \\
\text { Feb }-03 \\
P-14 \text { to } 17 .
\end{gathered}
$$




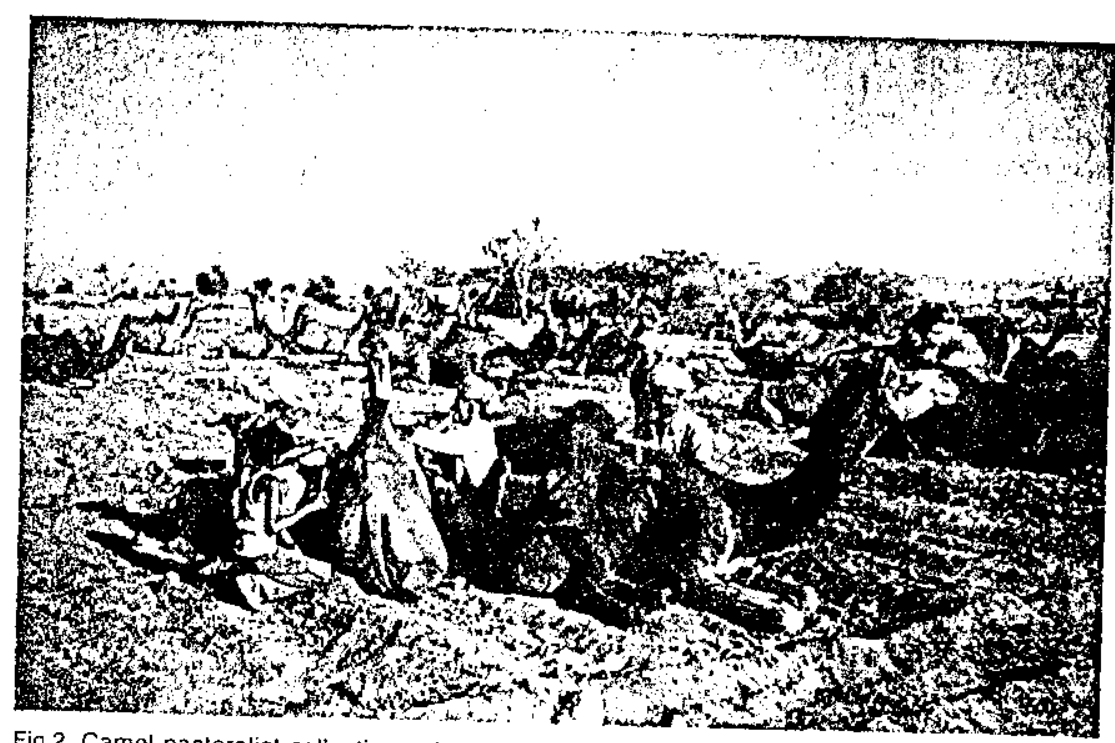

Fig.2. Camel pastoralist collecting animal hair production from camel.

where it is widely used as draft animal. To obtain optimum profit from rimol, it is (sisential to athopl scientific management practices.)

The grass root level study covered various aspects of camel rcaring system viz. social status of camel keepers, on-going agriculture practices, number of livestock, their camel breeding practices, commonly occurring diseases, health status, production aspects and sources of revenue of camel keepers etc. The required data were collected in the suitably developed and pre-tested proforma by survey method.

The selection of respondents was made by using multistage stratified random sampling technique. The study involved a total of 5 different tehsils of Bikaner and Churu district. Five different tehsils were categories into 4 different zone of Thar desert, viz. Nokha tehsil (South zone), Lunkarensar tehsil (North zone), Kolayat tehsil (West zone) and Sri Dungargarh tehsil (East zone). A sample of 20 households were drawn from each viliage randomly for data collection.

To obtain the estimates of rearing cost of animal and cost of crop cultivation, the opportunity cost of owned inputs and aclual prices paid by the farmers for purchasing inputs were eomsidered. "fo work oul the gross returns from different source of income of farmers, the market prices were considered. Finally, the economic estimates were carried out by tabular analysis.

Animal husbandary in the Thar region depends not only on the economic and social aspects of the migrating pastomalists bet also an the

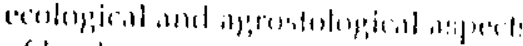

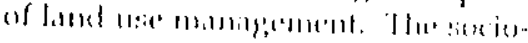
ecomomic states of camed keepers as well as communication ind trattsporl infrastructure are also very poor. In these districts land is duny and soils are low in nitrogen and organic matter content. It is naturaliy eroded by winds during Summer and the crop yields are low and unstable. Some of camel pastoralists follow a transmigratory systom of animal management.

In this study the average family size of camel pastoralists ranges from $5.25 \pm 1.33$ to $8.54 \pm 2.66$ with overall average of $6.70 \pm 0.59$ individuals. The overall number of female members are $3.49 \pm 0.26$ whereas male members are 3.21 t 0.36 . The literacy percentage varies from 26.22 to 32.11. Most of camel pastoralists are having misimum mon-iurigr,bled land. The overall average land holding was $29.90 \pm 1.01$ ha/farmer (non-irrigated), and $15.22 \pm 1.02 \mathrm{ha} /$ farmer (irrigated). Among the different categories of pastoralists marginal farmer formed the major group (92.50 to $96.14 \%)$ and few progressive larmers $(3.86$ to $7.50 \%$ )

Table 1. The average economic return of camel pastoralisls from agriculturo.

\begin{tabular}{llllll} 
Major crop & $\begin{array}{l}\text { Average } \\
\text { productivity } \\
\text { (tonne,ha }\end{array}$ & $\begin{array}{l}\text { Average } \\
\text { cosi of } \\
\text { (Rs/ha) }\end{array}$ & $\begin{array}{l}\text { Gross } \\
\text { return } \\
\text { (Rs/ha) }\end{array}$ & $\begin{array}{l}\text { Net return } \\
\text { (Rs/ha) }\end{array}$ & $\begin{array}{l}\text { Return/ } \\
\text { invested } \\
\text { (Rs) }\end{array}$ \\
\hline $\begin{array}{l}\text { Cluster bean } \\
\text { Desimoth }\end{array}$ & 0.489 & 3200 & 10758 & 7558 & 3.36 \\
\hline
\end{tabular}

Table 2. The average economic relurn of camel pastoralists from animal husbandry.

\begin{tabular}{|c|c|c|c|c|c|}
\hline Animal & $\begin{array}{l}\text { Averago } \\
\text { return }\end{array}$ & $\begin{array}{c}\text { Avoragis cost } \\
\text { of rearing } \\
\text { (As/animal } \\
\text { day) }\end{array}$ & $\begin{array}{l}\text { Gross } \\
\text { relumn } \\
\text { (Rs/animal/ } \\
\text { day) }\end{array}$ & $\begin{array}{c}\text { Not refuin } \\
\text { (Rs/animal/ } \\
\text { day) }\end{array}$ & $\begin{array}{l}\text { ricturn/ } \\
\text { invested (19s) }\end{array}$ \\
\hline $\begin{array}{c}\text { Cattle and } \\
\text { Bulfalo }\end{array}$ & $\begin{array}{c}\text { Milk - } 10 \\
\text { kg/day/animal }\end{array}$ & 55 & 100 & 45 & 1.82 \\
\hline Sheep & $\begin{array}{l}\text { Wool - } 2.50 \\
\text { kg'yrlanimal }\end{array}$ & 0 & $\begin{array}{r}213 / \\
\text { Ani } / Y \text { r }\end{array}$ & 0.58 & . \\
\hline Camel & Carting & 40 & 76 & 36 & 1.90 \\
\hline
\end{tabular}

Market prices letched by the farmers for calculating the gross return are taken as cluster bean ( Rs 2200/a. Moth \& Rs $2100 / \mathrm{q}$. milk \& Rs $101 / \mathrm{kg}$, and wool \& Rs $85 / \mathrm{kg}$ ). 
are also Ihere, Natiomal sample

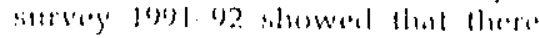
were $62.8 \%$ marginal farmers and $17.8 \%$ small holders. There had been a steady decrease in the size of land holding per person. The female members of pastoralist's family devoted maximum time $(81.85 \%)$ under village condition as compared to male members (18.15\%) with day to day management of camel. The major crop of kharif are clusterbean, moth, pearl millet, mung bean, rapeseed etc, whereas under irrigated belt, the rabi are mustard, chick pea, wheat etc.

The ratio of camel to other livestock species in difierent villages of Thar districts were analysed. The camel to sheep and goat ratio was highest (1: 12.45), followed by cattle ratio( $1: 8.56)$ and buffalo ratio (1:0.31). The overall camel and herbivore ratio was $1: 21.36$. The population cattle, buffalo, sheep and goat should be reduced to the optimum level and that camel based livestock system should be encouraged in the periphery of desertic land. There will be no loss to the land, food and milk production as camel will cause much less damage to the ecology than other livestock.

\section{CAMEL PRODUCTION AND \\ MANAGEMENT SYSTEM}

The overall average of dry fodder consumption of an adult camel was $6.43 \pm 0.23 \mathrm{~kg} /$ day during day whereas $5.61 \pm 0.22 \mathrm{~kg} /$ day during evening. The average time spend in ranged land for pasture grazing varied from $6.25 \pm 0.43 \mathrm{hr} /$ day to $10.54 \pm 0.31 \mathrm{hr} /$ day. The frequency of watering was twice in summer and once in rainy season and winter. As a special feeding farmers supplemented Molasses ( 300 to $700 \mathrm{~g}$ ), oil mainly of groundnut/seasame (250 to $600 \mathrm{~g}$ ), Alam (hydrated Aluminum potassium sulphate salt) (250 to 600 g). Occasionally ghee, fenugreek, turmeric are also offered to their studs, and breeding females and to their cart camel. The average number of stervicue replesud for conception varied from $1.78 \pm 0.2862 .56 \pm 0.2 \%$. Maximum responded $(72 \% \pm 4.86)$ reported common breeding season/ rutting is from December to March whereas few farmers $(28 \% \pm 4.94)$ reported from November to March.

The most useful animal of desert ecosystem - camel can tolerate high temperatures, solar radiation and water deprivation and subsists on poor quality thorny vegetation. The overali average annual ploughing by camel was $22.46 \pm 1.76$ days during kharif and $24.19 \pm 1.61$ days during rabi. It depends on land holding of camel farmers. The overall average of utilization of camel in ploughing was $10.15 \pm 0.36 \mathrm{hr} /$ day in kharif and $9.26 \pm 0.44 \mathrm{hr}$ in rabi. In this study area average milk yield varied from $3.5 \pm 0.50$ to $4.80 \pm 1.12 \mathrm{~kg} / \mathrm{day}$ and the lactation length ranged from 8.65 \pm 0.86 to $11.27 \pm 0.43$ months. The average annual hair yield in camel calves was found to be higher when compared with its adult. The overall average hair yield for camel calve was $1.39 \pm 0.17 \mathrm{~kg}$ and for adult camel was $0.97 \pm 0.25 \mathrm{~kg}$. Camel hair is used in village cottage industry for preparation of common utility items viz: rope, blankets, floor rugs, bags and mattresses etc. The handicraft articles made up of camel hair, provide work to rural women in grading of hair, tops preparation, spinning of hair, weaving, embroidery with $100 \%$ specialty hair and blending with sheep wool, goat hair, cotton and other products. The camel hair is widely used in rural cottage industry of Rajasthan and Gujarat for preparation of various items. The hair of dromedary camels are durable, strong and have low conductivity.

\section{HEALTH OF CAMEL}

The average annual mortality in young camel calves was maximum when compared with adult camel. The average mortality camel calves (up to 1 month age) varied from
$28.26 \% \pm 2.55$ to $39.24 \% \pm 2.11$

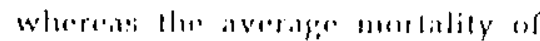

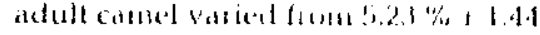
to $10.16 \% \pm 2.61$. The overall average annual mortality in young calves was $33.05 \% \pm 2.63$ whereas in adull, it was $8.10 \%+1.07$. The first ranking is obtained by parasitic mange which was varicd from $72.11 \%$ to $80.14 \%$ with overall frequency of $75.62 \% \pm$ 1.80. The area parasitic mange problem of camel was maximum/ highest. In south zone of Thar desert this problems was maximum $(80.14 \%)$. The occurrence of Surra (Trypanosomiasis) varied from $11.20 \%$ to $15.00 \%$ with an overall frequency of $12.79 \%$ \pm 0.80 and it was found mainly in irrigated area. Surra was followed by other health disorders. General fever was getting IIl ranking which was varied from $3.52 \%$ to $6.15 \%$ with overall frequency of $4.86 \% \pm 0.55$. Incidence of respiratory infection (pneumonia, coughing etc) got IV ranking and this problem was highest $(5.70 \%)$ at western zone. It varied from $2.99 \%$ to $5.70 \%$ with overall frequency of $3.96 \% \pm 0.60$. Other health problems like digestive disorders, diarrhoea, worm infesta-tion etc occured with a range from $2.12 \%$ to $3.80 \%$ and a overall frequency of $2.76 \% \pm 0.40$. No prophylactic measures were adopted in villages against parasitic or bacterial diseases. Although treat-ment against mange with Butox spray or Ivermection injection was reported from villages of south and east zone. As ethnoveterinary practice camel pastoralists used mobile oil/kerosine oil/sesame oil and Boric powder against mange infection, alcohol + onion for general fever and azoan + molasses for coughing problems.

\section{ECONOMIC ANALYSIS OF \\ CAMEL PASTORALISTS}

The success of livestock rearing revolve around communications network, efficient labour organization, functionally prescribed norms and social values of religious beliefs, gender role delineation and lechnolo- 
kerosine

powder cohol + azoan + ims. jOF iTs

s rearing ications rganizad norms is beliefs, technolo- rical comsideration. The pastoral production system must be amalysed from various aspects viz. pistoral comomics, socinl and organizationat structures inlegrated lo each other. Any analysis of camel pastoralism metes of production should focus on all these aspects of peoples live as these reliate to each other and to the snlire ecology of their lubitat. The protuctivity of two major crop commonly grown in this study area and their cost of cultivation along with relum etc were meticulously analysed. The average economic relurn of camel pastoralists from agriculture is elucidated in Table 1. The per hectare produclivity of clusterbean $(0.459$ tome/ha) was higher than desi Moth (0.275 lonne/ha). The average cost of cullivation were Rs $3200 /$ ha and Rs 2525/ha for clusterbean and desi Moth, respectively whereas gross return from cluslerbean was higher (Rs 10758) than moth (Rs 5 775). A similar trend was found in net return. clusterbean provides higher net retum (Rs 7558 ) than desi moth (Rs 3250 ). Return per Rupee invested was higher in clusterbenn (Rs. 3.36) when compared with desi moth (Rs 2.29). Due to higher production potential, increase market price and economic advantage clusterbean cultivation for camel pastoralist is more profitable than traditional moth cultivation.

The economic return of camel pastoralist form animal husbandary was also analysed. The average economic return of camel pastoralists from animal husbandary is given in Table 2. The major return from different animal sources were laken for economic calculation. The average return from cattle and buffalo was 10 $\mathrm{kg}$ milk/day/animal and from shecp was $2.50 \mathrm{~kg}$ wool/year/animal whereas camel delivered return through carting. The average cost of rearing of camel (Rs 40) was comparatively low as compared to cattle and buffalo (Rs 55). The sheep were reared in zero input basis (mainly on kitchen waste/grazing land). The net retum from cattle and buffalo was high (Rs 45/day/animal) when compared with camel (Rs 36/day/camel). The similar trend was observed in gross return. The gross return from cattle and buffalo, sheep and goat, camel were Rs 100/animal/day, Rs 213/animal/ year and Rs 76/camel/day, respectively. But finally return per rupee invested was quite high in camel (Rs 1.90) as compared to cattle and buffalo (Rs 1.82). This is mainly due to low rearing cost of camel than callte and buffato. The main objectioes of comed reving in Rajasthan is obviously animal power for pulling a calt or ploughing or as draft animal in ard regions. The livestock farming has more or less been stendy in spite of several severe droughts that the region experienced in recent years. There is a need for capital generation and raw material production for the industry to survive. An increase in demand for animal products in the urban consumer market is expected. The only source that is sustamable would be the small holder who generates producls at moderate cost, without draining natural resources and depending on import.

\section{SUMMARY}

To ensure a regular income and sufficient food for pastoralists and better living standards, it is necessary to go for some other alternate land usebased farming system or subsi-diary enterprises which will provide more income and employment to the pastoralists. Such enterprises include canel rearing/carting or other species. So there is a sign of hope to explore the income through camel production that exists for turning the pastoralist's economy viable.

\section{(Continued from page 3)}

\section{Productivity constraints of...}

awaremess, the sowing distance was not followed by the farmers. Very minor proportion of farmers followed the proper spacing. The reasons reported for non-adoption of sowing distance are the nom-availability of required implements.

The fertilizer application at the sowing was adopted by one-third sample farms. The reason behind non-adoption of fertilizer at the sowing was risk duc to uncertain monsoon (47\%).

Measures for improvement of productivity of rabi sorghum (i) The efforts are required to be

Fibrary 2003 made for adoption of complete package of production technology through proper and intensive extension programme.

(ii) Removal or minimization of the constraints of economical, technological, agro-climstological and other nature.

(iii) Suitable high-yiclding varieties and hybrids need to be developed, propagated and spread.

(iv) Development of drought-resistance varieties and better methods of water conservation to face vagaries of monsoon.

(v) Expansion of irrigation facilities to provide protective irrigation to enlance productivity.

\section{SUMMARY}

Rabi sorghum is the largest cereal crop grown in Maharashtra being ideal for rainfed regions. The low productivity in the slate and regioms variation in yickl is the mest limiting factor for chhancing production. The awareness of package of practices of ralli sorghum among the grower and aduption of the same needs to be enhanced through constant research, extension and induced inpul supply of right quality as well as quantity and at optimum time.

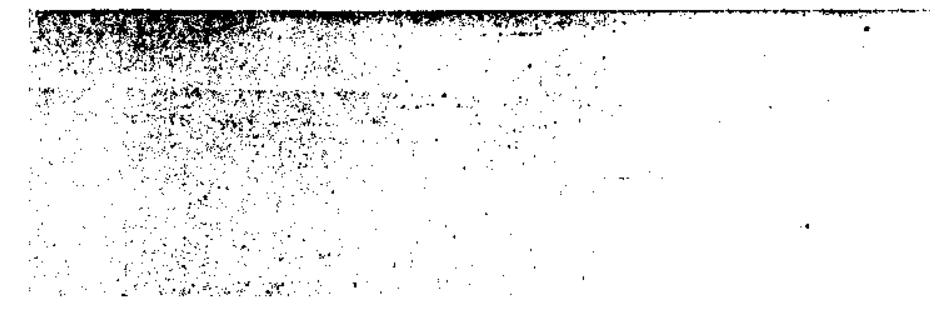

